\title{
Gene expression profile in zebu dairy cows (Bos taurus indicus) with mastitis caused by Streptococcus agalactiae
}

\author{
I. Fonseca ${ }^{a}$, F.F. Cardoso ${ }^{\text {b }}$, R.H. Higa ${ }^{\text {c }}$, P.F. Giachetto ${ }^{c}$, H.M. Brandão ${ }^{d}$, M.A.V.P. Brito ${ }^{d}$, \\ M.B.D. Ferreira ${ }^{\mathrm{e}}$, S.E.F. Guimarães ${ }^{\mathrm{a}}$, M.F. Martins ${ }^{\mathrm{d}, *}$ \\ a Departamento de Zootecnia, Universidade Federal de Viçosa, 36571-000 Viçosa, MG, Brazil \\ ${ }^{\mathrm{b}}$ Embrapa South Animal Husbandry \& Sheep, 96401-970 Bagé, RS, Brazil \\ ${ }^{\mathrm{c}}$ Embrapa Agriculture Informatics, 13083-886 Campinas, SP, Brazil \\ ${ }^{\mathrm{d}}$ Embrapa Dairy Cattle, 36038-330 Juiz de Fora, MG, Brazil \\ e Epamig, 38001-970, Uberaba, MG, Brazil
}

\section{A R T I C L E I N F O}

\section{Article history:}

Received 13 October 2014

Received in revised form

8 July 2015

Accepted 13 July 2015

\section{Keywords:}

Gyr

Immune response

Mammary

Mastitis

\begin{abstract}
A B S T R A C T
Mastitis is an inflammatory response in the mammary gland caused by an influx of somatic cells, composed mainly of neutrophils, macrophages and lymphocytes. The speed and efficacy of the host's immune response to the invasive pathogen affects the establishment, persistence and severity of the infection. To characterize the gene expression and response mechanism to infection by Streptococcus agalactiae (S. agalactiae) in zebu dairy cows of the Gyr breed, we carried out a transcriptome study of the cells present in the milk from 17 animals. Milk samples were collected before inoculation (hour 0 ) and 4 , 9 and $24 \mathrm{~h}$ after inoculation of the bacteria into one of the quarters and at 0 and $24 \mathrm{~h}$ from one of the quarters not inoculated. The transcriptome analysis was done by the microarray and real-time PCR techniques. The microarray technique revealed the existence of 32 differentially expressed genes between inoculation and $4 \mathrm{~h}$ afterward. The validation of these results by real-time PCR was done for eight genes. Besides these eight genes, the expression of six others was evaluated by real-time PCR even though they did not present a significant difference by the microarray technique. Of the 14 genes analyzed by real-time PCR, all showed a significant difference in expression for at least one of the comparisons between times. This analysis indicated an increase in the expression of all the genes that presented a significant difference in relation to hour 0 , with most of them presenting maximum expression $24 \mathrm{~h}$ after inoculation of the pathogen. Comparison of the gene expression between the inoculated and non-inoculated quarters showed greater expression in nine genes in the inoculated quarters. Analyses of gene networks revealed three modules with distinct characteristics $24 \mathrm{~h}$ after inoculation and showed that some mechanisms are altered in Gyr dairy cows after infection of the mammary gland by $S$. agalactiae. In this study it was possible to verify changes in the expression of at least 14 genes related to the immune response of zebuine animals against intramammary infection caused by S. agalactiae. These genes can play important roles in fighting intramammary infection and maintaining the tissue during infection.
\end{abstract}

(c) 2015 Elsevier B.V. All rights reserved.

\section{Introduction}

Mastitis is an inflammatory response of the mammary gland caused by metabolic and physiological changes, traumas, or more frequently by environmental or contagious pathogenic microorganisms (Oviedo-Boyso et al., 2007), including gram-negative and gram-positive bacteria, mycoplasmas and algae (Zadoks et al., 2011). This inflammatory response is characterized by an influx of

\footnotetext{
* Corresponding author. Fax: +55 3233117401.

E-mail address: marta.martins@embrapa.br (M.F. Martins).
}

somatic cells composed mainly of neutrophils, macrophages and lymphocytes (Rainard and Riollet, 2003), in which the speed and efficacy of the host's immune response against the invasive pathogen affects the establishment, persistence and severity of the infection (Bannerman, 2009). Besides the economic impact of this disease, due to alterations in the milk composition, reduced milk production and treatment costs, among others, it also is cause for concern regarding animal welfare and human health (Contreras and Rodríguez, 2011).

In bovines, mastitis is the only disease associated with infection by Streptococcus agalactiae, a gram-positive bacterium that is only transmitted contagiously within the herd, i.e., from one cow to 
another (Keefe, 1997; Neave et al., 1969). Because of the great importance as a pathogen causing mastitis, in 2011 the first sequence was published of the complete genome of a strain of $S$. agalactiae (FSL S3-026) isolated from a cow with clinical mastitis (Richards et al., 2011). Nevertheless, although in recent years a large variety of immunological profiles and associated responses have been described after infection of the mammary gland with gram-positive (Alluwaimi et al., 2003; Denis et al., 2006) and gram-negative bacteria (Lahouassa et al., 2007; Petzl et al., 2008), no article has specifically analyzed the response profile of zebu cattle (Bos taurus indicus) when infected by $S$. agalactiae.

Among the zebuine breeds, the Gyr breed is particularly well adapted to Brazilian environmental conditions. For this reason, it has been intensely used in crosses, and is the preferred breed for the formation of crossbred dairy herds in Brazil, responsible for roughly $70 \%$ of the country's milk production (Embrapa Gado, 2005). Data from the Brazilian Association of Artificial Insemination show that in 2013 the number of semen doses sold from Gyr Dairy sires was third among dairy breeds in Brazil. Nevertheless, despite this breed's importance to the dairy industry, few studies have been published identifying genes capable of conferring resistance to mastitis in animals other than taurine breeds (Bos taurus taurus). There are indications of the existence of differences in the response profile to clinical mastitis among Gyr, Holstein and cross-bred animals (Fonseca et al., 2009, 2011). Besides this, one of the main results of The Bovine HapMap Consortium (2009) was confirmation that cattle are divided into three main groups: European, Indian and African. For this reason, the response profile to various diseases in dairy cattle should be studied among different groups and breeds, so that these responses can be adequately compared to verify the similarities, differences, response mechanisms and possible particularities of prognosis and treatment.

Analyses of the overall profile of gene expression by means of the microarray technique have revealed the expression of various cytokines in infected udders (Günther et al., 2009, 2010; Lutzow et al., 2008). Other studies with gram-positive bacteria also have described a greater influx of leukocytes in the mammary gland and the expression of a large variety of cytokines and inflammatory mediators (Alluwaimi et al., 2003; Bannerman et al., 2004a, 2004b). However, all of these studies involve cattle of the Holstein breed. Based on these studies, the genes involved in the immune response have been indicated as likely candidates for understanding resistance and susceptibility to mastitis (Alluwaimi et al., 2003; Fonseca et al., 2009, 2011; Oviedo-Boyso et al., 2007). An ample analysis of the orchestrated interaction of cytokines and chemokines during mastitis caused by a specific pathogen can help to better understand the regulation of the immune response in the udder to this pathogen (Schukken et al., 2011). Therefore, the identification of factors that contribute to the predisposition of the mammary gland to mastitis will facilitate the development of new strategies to control this disease, such as identification of genes that can be used as markers for resistance to mastitis in animal breeding programs.

To contribute to this effort, we applied the microarray and realtime PCR techniques for the main purpose of characterizing the gene expression in cells present in the milk of Gyr cows artificially infected with $S$. agalactiae. This knowledge can be used for more efficient treatment, especially in B. taurus indicus animals, where the references are scarce and limited in scope.

\section{Material and methods}

\subsection{Experimental animals}

To select the animals of the experimental group, 105 Gyr dairy cows from the Getulio Vargas Experimental Farm of the Minas Gerais Agricultural Research Company, located in Uberaba (Minas Gerais, Brazil), were assessed regarding their history of mastitis between 2003 and 2007, order of calving and somatic cell count (SCC). Besides this, the animals were submitted to a series of three microbiological exams, performed according to NMC (1987), and only the cows that presented a negative result to $S$. agalactiae on all three tests were selected. A total of 17 animals, with an average of three calvings and at least 80 days of lactation.

The project was approved by the animal research ethics committee of the Embrapa Dairy Cattle Research Unit (Embrapa Gado de Leite), following the guidelines of Law 11,794/2008 and of Normative Resolution 1/2010 from the National Council for Control of Animal Experimentation of the Ministry of Science and Technology.

\subsection{Inoculation and collection of the samples}

Before experimentally induced intramammary infection, the 17 cows were submitted to clinical examination of the udder and the strip cup test after the first milking (procedure modified from Grönlund et al. (2006) and Lee et al. (2006)). The cows were inoculated with strain 8137 of $S$. agalactiae, isolated in a pure culture from the milk of a cow with subclinical mastitis sensitive to $\beta$ lactam antibiotics, belonging to the microorganism collection of Embrapa Dairy Cattle. The bacteria were seeded in plates containing blood agar medium, prepared with $5 \%$ defibrinated sheep blood, and afterward were transferred to brain heart infusion broth (BHI). To prepare the inoculum, the culture was centrifuged at $10,000 \mathrm{~g}$ for $10 \mathrm{~min}$. The pellet was ressuspended in $1 \mathrm{x}$ PBS (2.7 mM KCl; $2 \mathrm{mM} \mathrm{KH} \mathrm{KO}_{4} ; 137 \mathrm{mM} \mathrm{NaCl} ; 10 \mathrm{mM} \mathrm{Na}_{2} \mathrm{HPO}_{4} \mathrm{pH}$ 7.4) to a final concentration of $100 \mathrm{CFU} / \mathrm{mL}$ determined by spectrophotometer. The bacterial suspension was infused only in one mammary quarter of each cow (IQ-inoculated quarter). The other quarters were infused with sterile $1 \mathrm{X}$ PBS (NIQ-non-inoculated quarter) as described by Lee et al. (2006). Aliquots of $50 \mathrm{~mL}$ of milk were taken from the IQ before inoculation (time 0 ) and $24 \mathrm{~h}$ after inoculation to perform the SCC and microbiological examination, to confirm the infection, and at $0,4,9$ and $24 \mathrm{~h}$ for extraction of RNA. Milk samples were cultured using standard microbiologic methods. Briefly, $10 \mu \mathrm{L}$ of milk was streaked on a blood agar plate and the bacteria were identified by colony morphology and Gram stain. For gram-positive cocci, catalase test were performed to distinguish catalase negative and the CAMP test and growth on bile esculin agar were used to differentiate $S$. agalactiae. Aliquots of $50 \mathrm{~mL}$ of milk were also collected from the NIQ at 0 and $24 \mathrm{~h}$ from each animal for RNA extraction. The milk samples were placed in isothermal boxes with ice for transport to the laboratory.

To minimize the adverse effects and assure the welfare of the animals, they were examined by a veterinarian before, during and after the experiment. Just after the last collection ( $24 \mathrm{~h}$ after infection), a specific intramammary antibiotic to which the strain was sensitive was administered. From the start of the experiment and after the antibiotic treatment, the milk was discarded to comply with the waiting period. Besides this, the cows were kept isolated from the others on the farm and were only incorporated into the herd after confirmation of a cure by clinical and microbiological examination, which was repeated three times (30, 40 and 55 days post-infection). All the animals showed negative results for $S$. agalactiae after the third microbiological examination after antibiotic treatment. The microbiological and clinical examinations confirmed that the symptoms presented by the animals were from infection by $S$. agalactiae. 


\subsection{Isolation of RNA and quality control}

The total RNA was extracted from the lysed milk cells with the RNeasy Mini Kit (Qiagen, Valencia, CA, USA), described as Lee et al. (2006) and Leutenegger et al. (2000). Aliquots of $15 \mathrm{~mL}$ of milk were centrifuged at $6000 \mathrm{~g}$ for $10 \mathrm{~min}$ at room temperature. The pellets were washed twice in $7.5 \mathrm{~mL}$ PBS, ressuspended and lysed with $350 \mathrm{~mL}$ of lysis buffer according to the manufacturer's recommendations. After this step, the lysates were kept at $-80^{\circ} \mathrm{C}$ until RNA extraction. Digestion with DNase I (Qiagen) was performed to remove any contamination with genomic DNA. The concentrations of the samples were determined with a NanoDrop ND-1000 spectrophotometer (NanoDrop Technologies, Wilmington, DE, USA) and the quality of the total RNA was evaluated with an Agilent 2100 Bioanalyzer (Agilent, Palo Alto, CA, USA). As a procedure for standardization of RNA quality control, the average value of RIN (RNA integrity number) was 8 . All the samples were stored at $-80^{\circ} \mathrm{C}$ until use.

\subsection{Large-scale gene expression experiments}

Aliquots of the total RNA quantified and evaluated to assure integrity were hybridized with an Affymetrix GeneChip Bovine Genome Array chip (Affymetrix, Santa Clara, CA, USA). This chip contains over 23,000 bovine transcripts (the complete list can be accessed at http://www.affymetrix.com/support/technical/byproduct.affx?product=bovine). A GeneChip $30007 \mathrm{G}$ scanner (Affymetrix) was used to capture the images corresponding to the signal intensity from the hybridization, operated with the GeneChip Command Console software, and the Expression Console software (Affymetrix) was used to determine the hybridization quality. Computational packages from $\mathrm{R}$ ( $\mathrm{R}$ Development Core Team, 2012) were used to search for differentially expressed genes. The affy, simpleaffy and affyQCReport packages, part of the Bioconductor project (Gentleman et al., 2004), available at http:// bioconductor.org/biocLite.R, were used for quality control of each chip. Besides this, to achieve greater quality control and for preprocessing (transformation, background correction and summarization), of the data from the GeneChip, the RMAExpress freeware was used, available at http://rmaexpress.bmbolstad.com.

Of the 68 RNA samples extracted, 48 were selected according to the RNA quality for hybridization in the microarray chips. Of these, 21 were considered of poor or marginal quality regarding the percentage of present transcripts, background level, integrity of the endogenous control genes and RNA degradation, according to the statistics generated by the Bioconductor and RMAExpress packages. Hence, just 27 arrays that have passed all quality control checks were considered in the subsequent statistical analyses, remaining 12, eight, four and three chips for times $0,4,9$ and $24 \mathrm{~h}$, respectively.

For the microarray data, differentially expressed genes identification relied on the two-step mixed model approach proposed by Wolfinger et al. (2001), implemented using R/maanova package (Wu et al., 2003). The first step of this model removed the main effects from all nuisance factors averaged over all genes and can be written as

$Y_{i j k l}=\mu+T_{i}+C_{j}+A_{k(i \times j)}+r_{i j k l}$,

where $Y_{i j k l}$ is the normalized intensity value for time $(T) i$, cow $(C) j$, and array $(A) k$ within $T_{i}$ and $C_{j}$, whereas $\mu$ is a constant. Here $C_{j}$ accounts for repeated measures on the same cow across time. Note that no genetic effects were modeled in this step and all genespecific variation was left in the error term $r_{i j k}$, which, in the second step, became the response variable for a gene model, written as: $r_{i j k}=G_{k}+(T G)_{i k}+(T C)_{j k}+e_{i j k}$

here $G_{k}$ is the main effect of gene $k$; $(T G)_{i k}$ is the interaction between time $i$ and gene $k$, which is of primary interest measuring the treatment (time) effects on each gene, and $(T C)_{j k}$ is the interaction between cow $j$ and gene $k$, such that cow was a blocking factor due to repeated measures on time. Random terms were $C_{j}$, $A_{k(i \times j)}, r_{i j k},(T C)_{j k}$ and $e_{i j k}$, with the respective variances, $\sigma^{2}{ }_{C}, \sigma^{2}{ }_{A}, \sigma_{r}^{2}$, $\sigma^{2} T$, and $\sigma_{e(k)}^{2}$, where the $k$ subscript indicates heterogeneous error variances for each gene.

Significance of gene expression changes across time for a total of six possible contrasts $(0 \mathrm{hx} 4 \mathrm{~h} ; 0 \mathrm{hx} 9 \mathrm{~h} ; 0 \mathrm{hx} 24 \mathrm{~h} ; 4 \mathrm{hx} 9 \mathrm{~h}$; $4 \mathrm{hx} 24 \mathrm{~h} ; 9 \mathrm{hx} 24 \mathrm{~h}$ ) was assessed by $t$-tests using the James-Stein shrinkage concept (Cui et al., 2005). Critical values for these tests were defined by 500 permutations of the data. Finally, the $p$-values were adjusted to control the false discovery rate by the method of Storey (2002).

Finally, to visualize the gene expression profiles of the genes differentially expressed over time $(0,4,9$ and $24 \mathrm{~h})$, we constructed a Heatmap of the summarized expressions of each gene at each of the times using the $\mathrm{R}$ software and its Heatplus package (http://www.bioconductor.org/packages/2.10/bioc/html/Heatplus. html). The summarized expression of each gene was obtained by using the median value corresponding to each of the times, rescaled to have mean zero and standard deviation of one. To construct the hierarchical cluster of genes, associated with the Heatmap, we used absolute correlation as the measure of dissimilarity and the average linkage clustering strategy.

\subsection{Validation of the genes differentially expressed by real-time PCR}

Among the genes identified as differentially expressed in the microarray experiment, we selected eight for validation by realtime PCR because they perform important functions in the immune response (AATK-apoptosis-associated tyrosine kinase; CCL2chemokine C-C motif ligand 2; CCL20-chemokine C-C motif ligand 20; CD40-CD40 molecule; CSF2-colony stimulating factor 2; IL-1 $\beta$-interleukin $1 \beta$; INHBA-inhibin beta A; and NOS2A-nitric oxide synthase $2 A$ ). Besides these eight genes, we evaluated the expression of six others by real-time PCR, even though they did not present a significant difference by the microarray technique (IL-12-interleukin 12; IL-17-interleukin 17; TLR-2-Toll-like receptor 2; TLR-4-toll-like receptor 4; GRO- $\alpha$-growth related oncogene $\alpha$; and TGF- $\beta 1$-transforming growth factor $\beta 1$ ). We analyzed these genes' expression because according to some published articles, they can have important functions in the immune response to mastitis (Lahouassa et al., 2007; Oviedo-Boyso et al., 2007; Riollet et al., 2006).

For the real-time PCR, the first strand cDNA was synthesized with the SuperScript III First-Strand Synthesis System for RT-PCR (Invitrogen, Carlsbad, CA, USA), which includes RNase H. Reverse transcription was carried out on a control sample, which contained a mix of all the RNA samples extracted and all the components of the kit, except the SuperScript III RT enzyme, to confirm the absence of any contamination by genomic DNA during the real-time PCR. The cDNA synthesized was then stored at $-20^{\circ} \mathrm{C}$ until use.

The real-time PCR reactions were performed with the SYBR Green PCR Master Mix kit (Applied Biosystems, Foster City, CA, USA). The reactions were performed twice for each sample and amplified with the 7300 Real-Time PCR System (Applied Biosystems). Each reaction contained cDNA, a pair of primers (a concentration was optimized for each target) and PCR Master Mix in a final volume of $25 \mu \mathrm{L}$. A mixture containing all the PCR components, without cDNA, was used as a negative control for each reaction, besides the reverse transcription control, in which the sample that did not contain the SuperScript III RT enzyme was used as a template in the real-time PCR. The amplification 
Table 1

Sequences of primers employed in the real-time PCR.

\begin{tabular}{|c|c|c|c|}
\hline Gene & Forward primer & Reverse primer & Reference or ID ${ }^{\mathrm{a}}$ \\
\hline 18S rRNA & GTAACCCGTTGAACCCCATT & CCATCCAATCGGTAGTAGCG & Wang et al. (2005) \\
\hline AATK & TGGTGGCCGTGTCCTTCT & ACCCGATGCCTCCCTTCTTA & XM_588863 \\
\hline CCL2 & AGTCACCAGCAGCAAGTGTCCTAA & TTCTTGGGTTGTGGAGTGAGTGCT & NM_174006 \\
\hline CCL20 & CAGCAAGTCAGAAGCAAGCAA & СССАСTTCTTCTTTGGATCTGC & Günther et al. (2009) \\
\hline CD40 & AGGGCACCTTGAATACAGACACCA & ATGACACGTTGGAGAAGAAGCCGA & NM_001105611 \\
\hline CSF2 & CTCGCCTGAAGCTGTACAAGAA & TCGTAGTGGGTGGCCATCA & NM_174027.2 \\
\hline GAPDH & CCTGGAGAAACCTGCCAAGT & GCCAAATTCATTGTCGTACCA & Mount et al. (2009) \\
\hline GRO- $\alpha$ & CGCCTGTGGTCAACGAACT & CTTCACGCTCTGGATGTTCTTG & NM_175700 \\
\hline HPRT & GCCGACCTGTTGGATTACAT & ACACTTCGAGGGGTCCTTTT & Tao et al. (2004) \\
\hline IL-12 & TTAATTGAGGTCGTGGTAGAAGCTG & GGTCTCAGTTGCAGGTTCTTGG & Leutenegger et al. (2000) \\
\hline IL-17 & AGATATCCCTCTGTGATCTGGGAAG & CAGGACCAGGATCTCTTGCTGGATG & Riollet et al. (2006) \\
\hline IL-1 $\beta$ & CTCTCACAGGAAATGAACCGAG & GCTGCAGGGTGGGCGTATCACC & Lahouassa et al. (2007) \\
\hline INHBA & GGAGGGCAGAAATGAATGAACTTAT & TCTTCCTGGCTGTGCCTGAT & NM_174363.2 \\
\hline NOS2A & TTGATTGCACCGCTTGGA & TCATACAAGGAAGGCCCAAGAG & NM_001076799 \\
\hline RPLPO & CAACCCTGAAGTGCTTGACAT & AGGCAGATGGATCAGCCA & Mount et al. (2009) \\
\hline TGF- $\beta 1$ & CCTGAGCCAGAGGCGGACTAC & GCTCGGACGTGTTGAAGAAC & Lahouassa et al. (2007) \\
\hline TLR-2 & CAGTTTAACCCAGTGCCTTC & CTCCAACGTCTTCAGTTGCT & Ibeagha-Awemu et al. (2008) \\
\hline TLR-4 & ACTGCAGCTTCAACCGTATC & TAAAGGCTCTGCACACATCA & Ibeagha-Awemu et al. (2008) \\
\hline Ubiquitin & GGCAAGACCATCACCCTGGAA & GCCACCCCTCAGACGAAGGA & Singh et al. (2008) \\
\hline
\end{tabular}

${ }^{a}$ ID: GenBank accession number (http://www.ncbi.nlm.nih.gov).

conditions were $2 \mathrm{~min}$ at $50^{\circ} \mathrm{C}, 10 \mathrm{~min}$ at $95^{\circ} \mathrm{C}$, followed by 40 cycles of $15 \mathrm{~s}$ at $95^{\circ} \mathrm{C}$ and $1 \mathrm{~min}$ at $60^{\circ} \mathrm{C}$. At the end of each reaction, a denaturation curve was plotted to assure that each reaction produced a single fragment, that is, the curve contained only one dissociation peak.

The primers used to evaluate the expression of the genes are listed in Table 1. They were designed using the Primer Express program (Applied Biosystems) from the sequences obtained in the GenBank (http://www.ncbi.nlm.nih.gov) or data in the literature. The genes GAPDH (glyceraldehyde-3-phosphate dehydrogenase), $18 \mathrm{~S}$ rRNA, Ubiquitin, RPLPO (ribosomal protein large PO) and HPRT (hypoxanthine-guanine phosphoribosyltransferase) were tested for endogenous control. All the endogenous controls were evaluated regarding the shape of the amplification and dissociation curves. Then they were analyzed with the geNorm program (Vandesompele et al., 2002) and the two endogenous controls considered the most stable were Ubiquitin and RPLPO.

By the real-time PCR technique, besides the contrasts in the microarray analyses for the IQ $(0 \mathrm{hx} 4 \mathrm{~h} ; 0 \mathrm{hx} 9 \mathrm{~h} ; 0 \mathrm{hx} 24 \mathrm{~h}$; $4 \mathrm{hx} 9 \mathrm{~h} ; 4 \mathrm{hx} 24 \mathrm{~h} ; 9 \mathrm{hx} 24 \mathrm{~h}$ ), three other contrasts were considered for the NIQ $(0 \mathrm{~h}$ NIQx0 h IQ; $0 \mathrm{~h}$ NIQx24 h NIQ; $24 \mathrm{~h}$ NIQx24 h IQ). The cycle threshold (Ct) data obtained during the real-time PCR were exported to an Excel spreadsheet and analyzed with the REST 2009 program, developed by M. Pfaffl (Munich Technical University) and Qiagen, to obtain data on reaction frequency and to compare the difference in expression between treatments. This program can be downloaded from http://www. qiagen.com/products/rest2009software.aspx\#Tabs $=$ t2 and permits analysis of the differential expression with efficiency correction for each gene and with normalization for more than one endogenous control, besides being adequate for data whose variance can be large and that are not normally distributed. The coefficient of variation of the duplicates of the Ct of each sample did not exceed $5 \%$ and the amplification efficiency of all the genes considered in this study were close (data not shown).

\subsection{Construction and analysis of the gene networks}

The data obtained from the hybridization of the microarrays were also analyzed using the Weighted Gene Co-expression Network Analysis (WGCNA) method (Langfelder and Horvath, 2008). WGCNA is a method that identifies correlation patterns between genes and has been widely used to find clusters (called modules) of highly correlated (or co-expressed) genes, which can be involved in a single biological process.

Two sets of microarray data ( 0 and $24 \mathrm{~h}$ after inoculation of the IQ), with five animals each, were pre-processed using the affy and gcrma packages (Bioconductor) with the R software. Then a filter was applied so that only the transcripts present in all the samples were considered. By means of the method proposed by Fuller et al. (2007), the gene co-expression networks were identified separately for each group ( 0 and $24 \mathrm{~h}$ ), by means of the WGCNA package in the $\mathrm{R}$ software, and then these networks were compared to identify the modules not conserved between the two groups.

\section{Results}

Aseptically collected milk samples from all the animals were plated onto blood agar plates and revealed the presence of $S$. agalactiae in the IQ $24 \mathrm{~h}$ after intramammary inoculation. Also there was a sharp increase in the SCC between 0 and $24 \mathrm{~h}$, which can be observed in Fig. 1, supported by the Mann-Whitney test

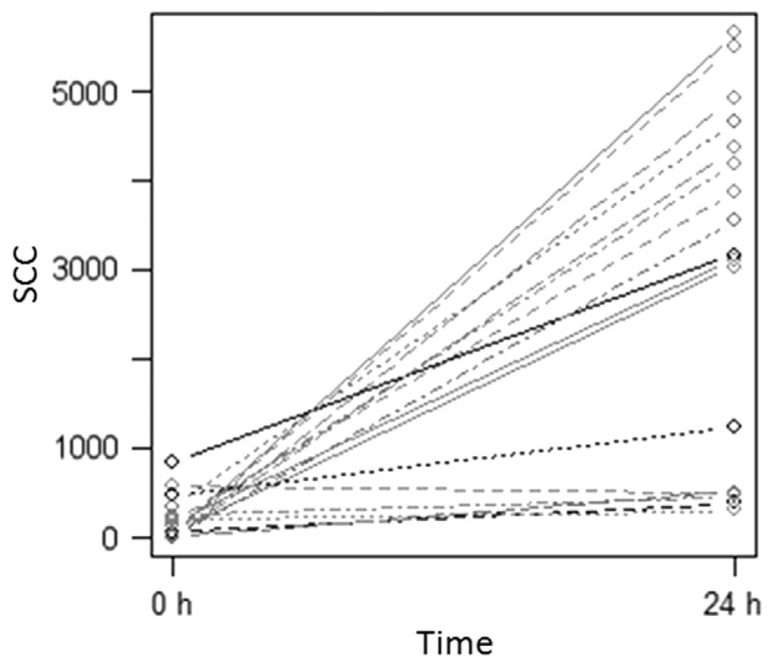

Fig. 1. Result of the somatic cell count (SCC) of the 17 cows at the time of inoculation of the strain of Streptococcus agalactiae in the inoculated quarter and $24 \mathrm{~h}$ later. 
Table 2

Genes differentially expressed by the microarray technique in the inoculated quarters by Streptococcus agalactiae in zebu dairy cows of the Gyr breed between 0 and $4 \mathrm{~h}$.

\begin{tabular}{llllll}
\hline Gene symbol & $\begin{array}{l}\text { Fold } \\
\text { change }\end{array}$ & $\boldsymbol{P}^{\mathbf{a}}$ & Gene symbol & $\begin{array}{l}\text { Fold } \\
\text { change }\end{array}$ & $\boldsymbol{P}^{\mathbf{a}}$ \\
\hline INHBA & 3.16 & 0.02 & TFRC & 1.77 & 0.03 \\
Gene not annotated & 3.13 & 0.01 & CISH & 1.76 & 0.03 \\
$\quad$ & & & & & \\
CH25H & 3.06 & 0.01 & PROCR & 1.76 & 0.02 \\
CCDC80 & 2.84 & 0.03 & CFB & 1.73 & 0.04 \\
IL-1 $\beta$ & 2.63 & 0.03 & Gene not anno- & 1.73 & 0.03 \\
MMP1 & & & tated 2 & & \\
CLDN1 & 2.19 & 0.03 & DCN & 1.7 & 0.03 \\
NUAK1 & 2.11 & 0.04 & IFI44 & 1.63 & 0.04 \\
AATK & 2.08 & 0.03 & TAP & 1.61 & 0.04 \\
NOS2 & 2.01 & 0.03 & PDXK & 1.59 & 0.05 \\
CCL20 & 2.01 & 0.04 & TM4SF1 & 1.57 & 0.03 \\
CCL2 & 1.94 & 0.04 & OAS1 & 1.55 & 0.04 \\
FGF2 & 1.93 & 0.04 & GJA1 & 1.55 & 0.03 \\
CSF2 & 1.88 & 0.04 & IL-1F6 & 1.53 & 0.04 \\
CD40 & 1.85 & 0.04 & CCNE2 & -1.76 & 0.03 \\
& 1.82 & 0.03 & Gene not anno- & -2.20 & 0.01 \\
\hline
\end{tabular}

${ }^{\mathrm{a}} P=$ adjusted $p$-values.

with $P<0.001$. These results assure that the experimental infections were successful. Furthermore, all the cows presented clinical mastitis $24 \mathrm{~h}$ after intramammary inoculation.

All told, 30 transcripts presented difference in the expression level $(P<0.05)$ in the IQ when analyzed by the microarray technique. However, differences in the expression level were only identified between 0 and $4 \mathrm{~h}$ of the IQ samples, as can be observed in Table 2.

In the real-time PCR analysis, all the investigated genes presented a significant difference $(P<0.05)$ in at least one of the comparisons made, as shown in Table 3. Besides this, the genes presented a similar expression profile by microarray and real-time PCR, i.e., the eight genes with significant expression difference by microarray had their expression increased at $4 \mathrm{~h}$ in relation to hour 0 , a condition confirmed by the real-time PCR technique in the samples collected from the IQ.

The gene network analysis identified 17 modules of co-expressed genes, three of them not conserved between the groups ( 0 and $24 \mathrm{~h}$ after inoculation of the IQ). These modules included 35, 37 and 192 genes, respectively. In the functional enrichment analysis, carried out with the Blast2GO software (http://www. blast2go.com/b2ghome), each of these modules presented distinct characteristics. Those in the first module (BTG3, CD3E, MBD1, CHIC2, PLXNA3, MOCS3, NEIL1, VPS45 and BCL2) were related to apoptosis and to antigen recognition. The second module was enriched in inflammatory mediators, including genes considered to be markers of mastitis (FGL1, GJA1, F2RL1, PTPRF, S100A2, TGF$\beta 2$ ), while the third module included genes involved in cell division and inflammatory responses (CD97, MAD2L1, ZFP106, CDKN2C, LOC514364, NOP14, PCBD1, LOC100139798, AP1S1, EDN1, IL-1 $\beta$, ANXA11).

Fig. 2 contains the Heatmap of the expression profiles of the differentially expressed genes, obtained by the microarray technique. As can be observed, the greatest expression difference among the genes identified by this technique occurred in the first four hours after infection, with the majority of the genes being upregulated at hour 4. In general, the differentially expressed genes showed an increase in expression in the first four hours after inoculation, and soon afterward the level of expression declined, in some cased gradually, such as DCN (decorin) and FGF2 (fibroblast growth factor 2), and in others abruptly, like $\mathrm{CH} 25 \mathrm{H}$ (cholesterol 25 hydroxylase) and GJA1 (gap junction protein alpha 1 ). Other genes maintained relatively constant expression level after the four-hour mark, such as $I L-1 \beta$ and NOS2.

In the present study, we noted that NOS2A gene's expression is altered following experimentally induced infection by $S$. agalactiae, with the expression at $4 \mathrm{~h}$ being twice that at hour 0 according to the microarray technique $(P<0.05$-Table 2$)$ and up to 12 times higher $24 \mathrm{~h}$ after inoculation according to real-time PCR $(P<0.01$ Table 3). And also we observed an increase in the expression of $C D 40$, both by the microarray technique and real-time $P C R$ $(P<0.05$ and $P<0.001$, respectively). By the microarray technique, its expression increased almost twofold at $4 \mathrm{~h}$ in relation to hour 0 (Table 2) and by real-time PCR it presented significantly higher expressions at 4, 9 and $24 \mathrm{~h}$ after inoculation, but no significant differences between these three times $(P>0.05$-Table 3$)$. As can be seen in Fig. 3a, this gene was one of those that maintained high expression during practically the entire period analyzed in the experiment, together with INHBA (Fig. 3b). Fig. 3a also shows the increase in the expression of the AATK gene after inoculation $(P<0.001)$ as well in the expression of the CSF2 gene $(P<0.05)$, in at least one of the contrasts carried out.

Among the differentially expressed genes identified by the realtime PCR, both the TLR- 2 and TLR-4 genes showed a significant increase in the expression level (about six-fold) between 0 and $24 \mathrm{~h}(P<0.001$ and $P<0.01$, respectively), as can be observed in Fig. $3 \mathrm{~b}$ and Table 3 . This difference also was observed between 4 and $24 \mathrm{~h}$, with the same probability values, and also between 9 and $24 \mathrm{~h}(P<0.01$ and $P<0.05$, respectively $)$, showing there was a gradual increase in the expression of these genes up to $24 \mathrm{~h}$ after inoculation of the pathogen (Fig. 3b). This situation is even more evident when comparing the NIQ with the IQ in Fig. 4, in both cases $24 \mathrm{~h}$ after inoculation, showing greater expression of TLR-2 and TLR-4 in the IQ $(P<0.001$ and $P<0.05$, respectively), i.e., at the infection site.

In general there was an increase in the expression of TGF- $\beta 1$ at all times analyzed in relation to hour 0 , with a significant difference $(P<0.05)$ in the $0 \mathrm{hx} 4 \mathrm{~h}$ and $0 \mathrm{hx} 24 \mathrm{~h}$ contrasts for the IQ (Table 3). At $9 \mathrm{~h}$, there was a decline in the levels of TGF- $\beta 1$, which then increased at $24 \mathrm{~h}$, a fact shown by the twofold increase in this gene's expression $(P<0.05$-Fig. $3 \mathrm{~b}$ and Table 3$)$. For this reason, there was downregulation between 4 and $9 \mathrm{~h}(P<0.05)$ and no significant difference between 0 and $9 \mathrm{~h}(P>0.05)$.

We noted a significant twofold increase in the expression of $I L-1 \beta$ gene by the microarray technique $4 \mathrm{~h}$ after inoculation $(P<0.05$-Table 2$)$, a finding validated by real-time PCR, in which $I L-1 \beta$ presented 25 times greater expression in the same time frame $(P<0.001-\mathrm{Ta}-$ ble 3). However, this difference in the level of expression diminished with time passed thereafter, being 12 times higher after $9 \mathrm{~h}(P<0.001)$ and 8 times higher after $24 \mathrm{~h}(P<0.001)$ (Table 3 and Fig. 3a). Therefore, between $4 \mathrm{~h}$ and $24 \mathrm{~h}$ after inoculation, the expression of $I L-1 \beta$ decreased by a factor of $3(P<0.01)$, but it was still 8 times higher than before experimentally induced intramammary infection. We also noted a difference in the expression of this cytokine between hours 0 and 24 from the samples collected from the NIQ (approximately four times greater, $P<0.05$-Table 3 ). However, the difference was greater (about eight times) in the milk from the IQ $(P<0.001)$, showing that the main expression of $I L-1 \beta$ occurs at the infection site (Fig. 3a and Table 3).

In this work, the expression of IL-17, a key component of the $\mathrm{T}_{\mathrm{H}} 17$ response, also increased when analyzed by real-time PCR, being differentially expressed in nearly all the contrasts $(P<0.05)$, except between 9 and $24 \mathrm{~h}$, despite showing a trend to continue increasing (Table 3 and Fig. 3b). This cytokine's expression increased up to 23 times between 0 and $24 \mathrm{~h}$ in the IQ samples $(P<0.001)$, but this gene did not present a significant difference in the microarray analyses. 
Table 3

Relative expression by the real-time PCR technique.

\begin{tabular}{|c|c|c|c|c|c|c|c|c|c|c|c|c|c|c|c|}
\hline & & \multicolumn{14}{|l|}{ Gene } \\
\hline & & AATK & CCL2 & CCL20 & CD40 & CSF2 & GRO- $\alpha$ & IL-12 & IL-17 & IL- $1 \beta$ & INHBA & NOS2A & TGF- $\beta 1$ & TLR-2 & TLR-4 \\
\hline \multirow[t]{3}{*}{$0 \mathrm{~h} \mathrm{IQ}^{\mathrm{a}} \times 4 \mathrm{~h} \mathrm{IQ}$} & $\begin{array}{l}\text { Relative } \\
\text { expression }^{\mathrm{c}}\end{array}$ & 0.53 & 3.53 & 1.84 & 7.07 & 3.06 & 2.68 & 3.31 & 3.98 & 25.26 & 6.78 & 0.99 & 1.86 & 1.58 & 0.76 \\
\hline & Standard error & $0.06-5.14$ & $1.17-11.60$ & $0.44-8.14$ & $1.42-35.11$ & $0.62-9.94$ & $0.53-9.57$ & $0.56-18.83$ & $0.67-19.90$ & $\begin{array}{l}3.35- \\
208.24\end{array}$ & $1.68-31.49$ & $0.17-6.20$ & $0.56-6.43$ & $0.63-3.75$ & $0.07-9.08$ \\
\hline & Probability $^{\mathrm{d}}$ & 0.243 & $<0.001$ & 0.097 & $<0.001$ & 0.002 & 0.042 & 0.012 & 0.002 & $<0.001$ & $<0.001$ & 0.971 & 0.038 & 0.052 & 0.632 \\
\hline \multirow[t]{3}{*}{0 h IQx9 h IQ } & Relative expression & 2.8 & 1.43 & 1.4 & 11.5 & 1.88 & 1.77 & 2.36 & 10.03 & 12.36 & 6.56 & 1.59 & 1.16 & 1.55 & 1.3 \\
\hline & Standard error & $0.11-61.75$ & $0.41-4.76$ & $0.28-6.67$ & $\begin{array}{l}2.98- \\
48.81\end{array}$ & $0.31-8.93$ & $0.37-6.46$ & $0.40-13.52$ & $1.75-65.24$ & $1.63-88.45$ & $1.51-29.82$ & $0.24-10.06$ & $0.40-3.84$ & $0.46-3.96$ & $0.11-14.35$ \\
\hline & Probability & 0.185 & 0.241 & 0.37 & $<0.001$ & 0.177 & 0.267 & 0.049 & $<0.001$ & $<0.001$ & $<0.001$ & 0.292 & 0.605 & 0.181 & 0.641 \\
\hline \multirow[t]{3}{*}{0 h IQx24 h IQ } & Relative expression & 11.17 & 2.07 & 13.21 & 8.47 & 8 & 6.47 & 21.94 & 23.12 & 7.55 & 8.51 & 12.37 & 2.14 & 6.34 & 5.84 \\
\hline & Standard error & $0.80-97.62$ & $0.56-7.56$ & $\begin{array}{l}0.65- \\
178.89\end{array}$ & $\begin{array}{l}1.48- \\
44.72\end{array}$ & $\begin{array}{l}0.98- \\
67.21\end{array}$ & $\begin{array}{l}1.21- \\
21.59\end{array}$ & $\begin{array}{l}1.07- \\
387.90\end{array}$ & $1.40-502.61$ & $1.12-49.31$ & $1.52-50.22$ & $\begin{array}{l}0.45- \\
259.61\end{array}$ & $0.58-7.10$ & $1.71-28.48$ & $\begin{array}{l}0.50- \\
64.57\end{array}$ \\
\hline & Probability & $<0.001$ & 0.029 & $<0.001$ & $<0.001$ & $<0.001$ & $<0.001$ & $<0.001$ & $<0.001$ & $<0.001$ & $<0.001$ & 0.003 & 0.025 & $<0.001$ & 0.009 \\
\hline \multirow[t]{3}{*}{4 h IQx9 h IQ } & Relative expression & 5.25 & 0.4 & 0.76 & 1.87 & 0.62 & 0.66 & 0.72 & 2.52 & 0.49 & 0.97 & 1.61 & 0.63 & 0.98 & 1.73 \\
\hline & Standard error & $0.22-173.28$ & $0.12-1.51$ & $0.24-2.90$ & $0.57-8.81$ & $0.08-4.39$ & $0.20-2.21$ & $0.15-2.85$ & $0.48-11.91$ & $0.08-3.13$ & $0.26-3.14$ & $0.39-6.24$ & $0.26-1.58$ & $0.30-2.57$ & $0.15-21.49$ \\
\hline & Probability & 0.057 & 0.006 & 0.383 & 0.067 & 0.369 & 0.188 & 0.357 & 0.033 & 0.12 & 0.912 & 0.167 & 0.041 & 0.94 & 0.346 \\
\hline \multirow[t]{3}{*}{4 h IQx24 h IQ } & Relative expression & 20.93 & 0.59 & 7.18 & 1.2 & 2.62 & 2.41 & 6.63 & 5.81 & 0.3 & 1.26 & 12.56 & 1.15 & 4 & 7.72 \\
\hline & Standard error & $1.27-413.76$ & $0.14-2.32$ & $0.44-96.11$ & $0.30-6.54$ & $\begin{array}{l}0.21- \\
27.52\end{array}$ & $0.71-8.32$ & $\begin{array}{l}0.35- \\
121.26\end{array}$ & $0.37-99.82$ & $0.05-1.77$ & $0.26-5.57$ & $\begin{array}{l}0.37- \\
214.70\end{array}$ & $0.38-3.40$ & $1.00-16.77$ & $0.55-97.27$ \\
\hline & Probability & $<0.001$ & 0.125 & 0.004 & 0.642 & 0.099 & 0.009 & 0.008 & 0.011 & 0.009 & 0.581 & 0.001 & 0.598 & $<0.001$ & 0.003 \\
\hline \multirow[t]{3}{*}{9 h IQx24 h IQ } & Relative expression & 3.99 & 1.45 & 9.47 & 0.72 & 4.26 & 3.66 & 9.28 & 2.31 & 0.61 & 1.3 & 7.81 & 1.85 & 4.1 & 4.48 \\
\hline & Standard error & $0.10-161.91$ & $0.33-6.21$ & $\begin{array}{l}0.55- \\
124.54\end{array}$ & $0.23-2.72$ & $\begin{array}{l}0.35- \\
59.45\end{array}$ & $\begin{array}{l}1.05- \\
12.38\end{array}$ & $\begin{array}{l}0.42- \\
154.78\end{array}$ & $0.17-57.96$ & $0.14-2.79$ & $0.27-5.71$ & $\begin{array}{l}0.27- \\
139.51\end{array}$ & $0.68-5.92$ & $\begin{array}{l}0.90- \\
20.81\end{array}$ & $\begin{array}{l}0.34- \\
56.21\end{array}$ \\
\hline & Probability & 0.135 & 0.295 & $<0.001$ & 0.343 & 0.03 & $<0.001$ & 0.002 & 0.223 & 0.216 & 0.5 & 0.006 & 0.023 & 0.004 & 0.021 \\
\hline \multirow{3}{*}{$0 \mathrm{~h} \mathrm{NIQ}^{\mathrm{b}} \times 0 \mathrm{~h} \mathrm{IQ}$} & Relative expression & 0.6 & 2.09 & 3.18 & 0.72 & 0.62 & 1.17 & - & 1.71 & 0.61 & 0.76 & 0.03 & 0.37 & 2.68 & 0.78 \\
\hline & Standard error & $0.04-18.62$ & $0.83-5.13$ & $0.50-18.14$ & $0.14-3.36$ & $0.10-4.71$ & $0.31-6.47$ & - & $0.14-21.33$ & $0.06-5.70$ & $0.14-3.84$ & $0.01-0.18$ & $0.09-1.53$ & $1.01-7.60$ & $0.07-11.62$ \\
\hline & Probability & 0.455 & 0.006 & 0.02 & 0.44 & 0.344 & 0.789 & - & 0.364 & 0.421 & 0.511 & $<0.001$ & 0.003 & $<0.001$ & 0.689 \\
\hline \multirow[t]{3}{*}{0 h NIQx24 h NIQ } & Relative expression & 0.54 & 0.73 & 1.25 & 0.96 & 2.85 & 1.27 & - & 0.78 & 4.22 & 2.07 & 1.13 & 0.89 & 1.43 & 0.83 \\
\hline & Standard error & $0.02-16.42$ & $0.27-1.96$ & $0.21-7.58$ & $0.23-3.45$ & $\begin{array}{l}0.36- \\
26.31\end{array}$ & $0.29-5.89$ & - & $0.05-10.55$ & $0.42-38.00$ & $0.47-10.58$ & $0.29-4.12$ & $0.24-3.31$ & $0.44-4.80$ & $0.06-11.60$ \\
\hline & Probability & 0.458 & 0.328 & 0.639 & 0.921 & 0.067 & 0.536 & - & 0.722 & 0.02 & 0.059 & 0.712 & 0.726 & 0.237 & 0.751 \\
\hline \multirow[t]{3}{*}{24 h NIQx24 h IQ } & Relative expression & 12.374 & 5.94 & 33.585 & 6.336 & 1.727 & 5.94 & - & 50.544 & 1.089 & 3.133 & 0.296 & 0.892 & 11.936 & 5.54 \\
\hline & Standard error & $0.56-271.20$ & $\begin{array}{l}1.21- \\
27.98\end{array}$ & $1.68-465.92$ & $\begin{array}{l}1.48- \\
32.78\end{array}$ & $0.15-20.14$ & $\begin{array}{l}1.41- \\
24.95\end{array}$ & - & $\begin{array}{l}3.06- \\
1.047 .17\end{array}$ & $0.17-6.63$ & $0.67-14.08$ & $0.01-4.40$ & $0.24-3.09$ & $\begin{array}{l}2.50- \\
63.03\end{array}$ & $\begin{array}{l}0.40- \\
64.50\end{array}$ \\
\hline & Probability & 0.003 & $<0.001$ & $<0.001$ & $<0.001$ & 0.338 & $<0.001$ & - & $<0.001$ & 0.858 & 0.004 & 0.09 & 0.73 & $<0.001$ & 0.013 \\
\hline
\end{tabular}

a $\mathrm{IQ}=$ inoculated quarter.

${ }^{\mathrm{b}} \mathrm{NIQ}=$ non-inoculated quarter.

c Numbers greater than $1=$ higher expression at the second time; numbers less than $1=$ higher expression at the first time.

${ }^{\mathrm{d}}$ Results with $P<0.05$ were considered significant. 

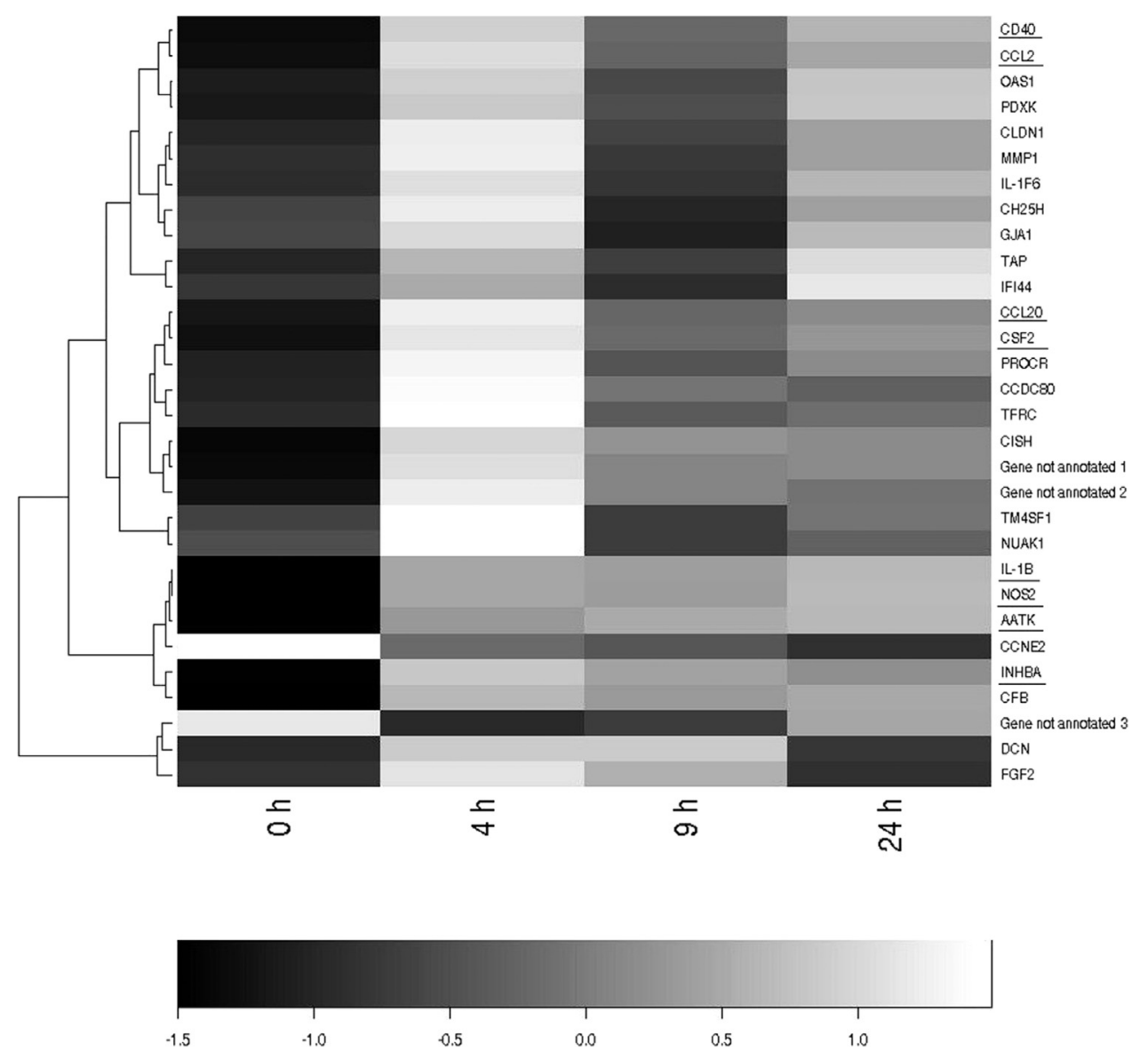

Fig. 2. Heatmap of the expression profiles of the differentially expressed genes by the microarray technique. The darker color represents the downregulated genes and the lighter color the upregulated genes. The underlined genes are those whose expression was validated by real-time PCR.
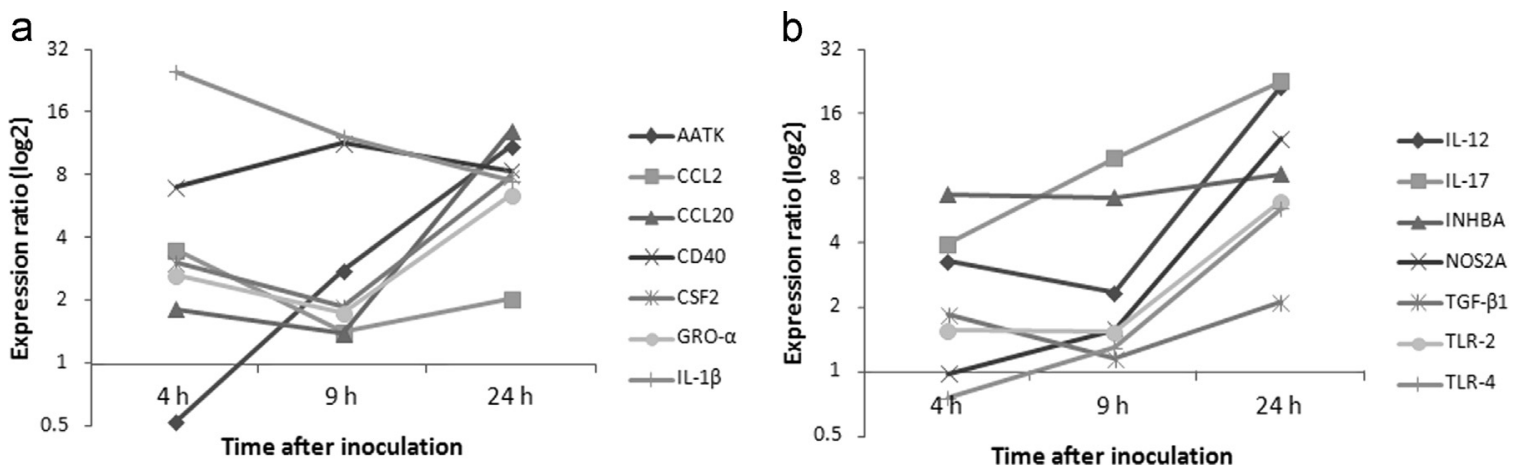

Fig. 3. Ratio of the gene expression at 4, 9 and $24 \mathrm{~h}$ after inoculation of the strain of Streptococcus agalactiae in relation to hour 0 by the real-time PCR technique.

We noted that the expression of GRO- $\alpha$ increased at hour 4 in relation to hour 0 and at hour 24 in relation to hours 0,4 and 9, with the greatest difference being between 0 and $24 \mathrm{~h}$, in which the expression was nearly seven times higher $(P<0.001$-Table 3 and Fig. 3a). Another cytokine, IL-12, presented increased expression by real-time PCR at hours 4, 9 and 24 in relation to hour 0 and at hour 24 in relation to hours 4 and 9 . Only not presenting a significant difference $(P>0.05)$ between hours 4 and 9 (Table 3 and Fig. 3b). Along with IL-17, IL-12 was one of the cytokines that presented the highest expression levels at hour 24, about 22 times higher than at hour $0(P<0.001)$.

Both the microarray and real-time PCR analyses revealed variations in the expression of the mRNA from the chemokines CCL2 and CCL20 (Tables 2 and 3). The expression profile of CCL2 was very similar to that of $T G F-\beta 1$, with reduced expression at hour
9 in relation to the base level of this chemokine, but with predominance of higher expression levels in relation to hour 0 during the entire period of the experiment (Fig. 3a). A similar profile was also observed for the CCL20 gene, but its peak expression occurred at hour 24, while the peak of CCL2 happened at hour 4 (Fig. 3a).

In general we observed a significant difference $(P<0.05)$ in the expression of five genes among the samples from the IQ and NIQ before inoculation (Table 3 and Fig. 5) and nine genes considered in this study $24 \mathrm{~h}$ after inoculation between the IQ and NIQ (Table 3 and Fig. 4).

\section{Discussion}

The host has to respond quickly and effectively against the invading pathogen, therefore the reaction against pathogens 


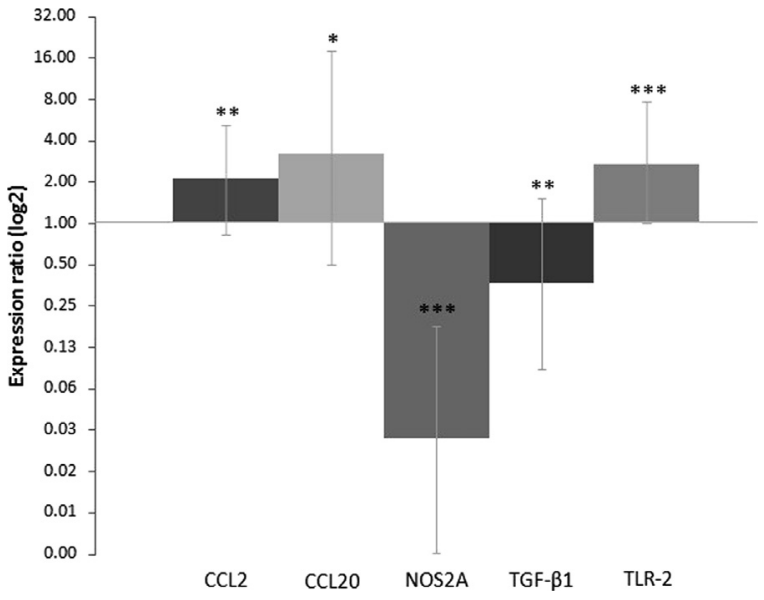

Fig. 4. Expression level of the genes with statistical difference $24 \mathrm{~h}$ after inoculation with the Streptococcus agalactiae strain from the inoculated quarter (IQ) in relation to the non-inoculated quarter (NIQ) $\left({ }^{*} P<0.05\right.$; ${ }^{* *} P<0.01$; ${ }^{* * *} P<0.001$ ).

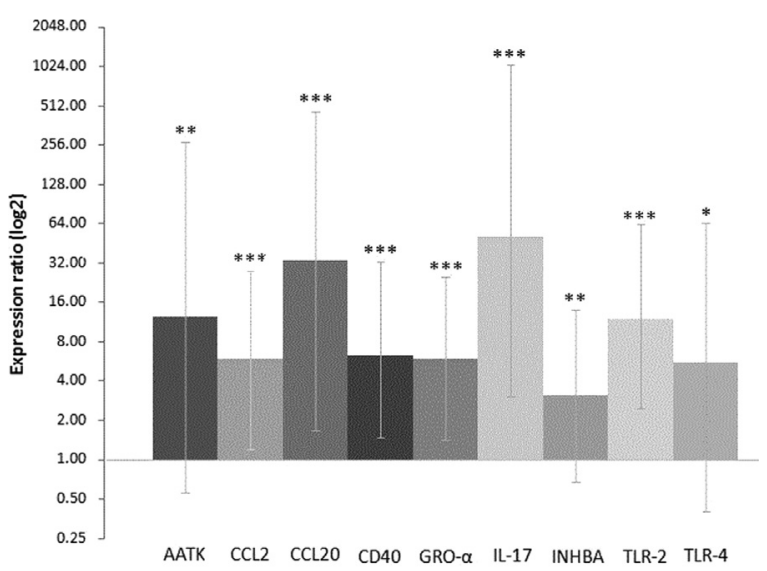

Fig. 5. Level of expression of the genes with statistically significant differences before inoculation of the Streptococcus agalactiae strain $(0 \mathrm{~h})$ from the inoculated quarter (IQ) in relation to the non-inoculated quarter (NIQ) $\left({ }^{*} P<0.05\right.$; ${ }^{* *} P<0.01$; *** $P<0.001)$

present in the mammary gland is governed by responses that occur within a few hours of initial infection (Bannerman, 2009). For this reason, we expected a large difference in the gene expression profile in the first hours after inoculation of the strain. Furthermore the results of gene network analysis show there are mechanisms that were altered in the Gyr cows after infection of the mammary gland by $S$. agalactiae.

In the mammary gland, the immune system cells, together with the epithelium cells, are activated through recognition of the pathogen-associated molecular patterns (PAMPs) of the invading microorganism via TLRs (Griesbeck-Zilch et al., 2008; Rainard and Riollet 2006). TLR-4 recognizes lipopolysaccharides (LPS) from gram-negative bacteria while TLR-2 recognizes the lipoteichoic acid (LTA) and peptidoglycan (PGN) present in gram-positive bacteria, such as S. agalactiae (Oviedo-Boyso et al., 2007). Recognition of the pathogen is the critical first step to mount an effective immune defense against the invading microorganism (Rinaldi et al., 2010). As in the present study, Goldammer et al. (2004) found an increase in the expression of both TLR-2 and TLR-4 in udders infected with Staphylococcus aureus, a gram-positive bacterium, as is S. agalactiae and suggested that the expression of these two receptors is regulated jointly during the start of the immune response in the udder. Other authors have also observed an increase in the expression of TLR-2 and TLR-4 in mammary tissue after experimental in vivo infection with Escherichia coli
(Petzl et al., 2008). The activation of Toll-like receptors leads to the expression of inflammatory cytokines and other mediators involved in the immune response, cell differentiation and apoptosis (Cates et al., 2009; Ibeagha-Awemu et al., 2008; Yang et al., 2008).

In the present study we observed an increase in the expression of NOS2A and CD40. Lutzow et al. (2008) also found an increase in the expression of NOS2A in mammary tissue infected by $S$. aureus, while Günther et al. (2009) noted the same effect when the infection was caused by E. coli. The NOS2A gene also participates in the innate immune response and its expression is regulated by signals from Toll-like receptors (Günther et al., 2009). The CD40 gene is a member of the superfamily of tumor necrosis factor (TNF) receptors and encodes a protein cell membrane receptor that has a synergetic role in the signaling triggered by Toll-like receptors. Because this gene is a co-stimulator of both $T$ and $B$ lymphocytes, our result can indicate that these lymphocytes were stimulated during the experimental period. In cattle, the B cells stimulated via CD40 and in the presence of TGF- $\beta$ and IL-2 increase the production of IgA (Estes et al., 1998), an important antibody isotype that is responsible for immunity of the mucosa, of which the lactating mammary gland is part (Brandtzaeg, 2010; Fagarasan and Honjo, 2004).

Although inflammation is an essential component of the host's response to intramammary infection, a prolonged inflammatory response can damage the mammary secretory epithelium and cause a permanent reduction in milk production (Long et al., 2001; Paape et al., 2003). In this context, the participation of anti-inflammatory cytokines such as IL-10 and members of the TGF- $\beta$ family (Grutz, 2005) is extremely important to minimize the effects of inflammatory cytokines. In agreement with our results, Chockalingam et al. (2005) noted an increase in the expression of the protein TGF- $\beta 1$ in milk from cows with udders infected with $E$. coli, while Bannerman et al. (2005) found the same effect when the mastitis was experimentally induced by Pseudomonas aeruginosa. However, Lahouassa et al. (2007) did not find any variation in the expression of TGF- $\beta 1$ in mammary epithelial cells infected in vitro by $S$. aureus or $E$. coli, and suggested that perhaps these cells are not a source of the TGF- $\beta 1$ found in the milk samples following experimentally induced infection. TGF- $\beta$ has immunosuppressive activity, but also has effects on cell proliferation and differentiation. It has been suggested that during infection of the mammary gland, TGF- $\beta$ is probably produced by leukocytes that invade the udder (Schukken et al., 2011). For this reason, we expected there to be an increase in the expression of this gene with the increase in the number of somatic cells. We should point out that in this work the RNA was obtained from somatic cells present in the milk, so cells from various sources can be present, explaining the apparent divergence in results. Besides this, we used zebu animals in this study, unlike others breeds used in previous studies.

The damage to the mammary tissue can be induced by apoptosis or necrosis (Zhao and Lacasse, 2008), and curiously, when there is an increase in the number of apoptotic cells there is also a higher proliferation of epithelial cells, which can be a mechanisms to maintain alveolar integrity (Kerr and Wellnitz, 2003). The INHBA gene is a ligand of the TGF- $\beta$ superfamily (Gaddy-Kurten et al., 1995) and also has a function related to apoptosis, as does the AATK gene. Sheffield (1997) found that induction of apoptosis in the mammary gland after experimental infection with $S$. agalactiae, could explain the increase in the expression of these genes.

IL- $1 \beta$ is one of the most important inflammatory cytokines because it acts as a mediator of both the systemic and local immune response. According to Schukken et al. (2011), IL-1 $\beta$ not only regulates the expression of a variety of genes involved in the immune response, but also genes involved in cell proliferation and apoptosis. Because it is a key component of the innate immune response (Lahouassa et al., 2007), we expected an increase in the 
expression of this cytokine in the first hours after infection. Our results show the importance of this cytokine in the immediate response to intramammary infection in Gyr dairy cows, with its expression peaking four hours after infection. These results are in agreement with the findings of Strandberg et al. (2005) who showed that the expression of $I L-1 \beta$ increased rapidly in the first two hours after in vitro stimulation of mammary epithelial cells by LPS or LTA. Lahouassa et al. (2007) also observed peak expression of $I L-1 \beta$ in the first hours after infection ( $3 \mathrm{~h}$ ) when mammary epithelial cells were stimulated with different strains of $S$. aureus. However, when these cells were stimulated in vitro with $E$. coli, the peak expression of this cytokine occurred at $24 \mathrm{~h}$ afterward.

Our results corroborate the idea that IL-17 and IL-12 also have a pro-inflammatory function during bovine mastitis caused by $S$. agalactiae in zebu animals. According to Kolls et al. (2008), proinflammatory cytokines like IL- $1 \beta$ can facilitate induction of the $\mathrm{T}_{\mathrm{H}} 17$ response, which in turn induces the antimicrobial response by epithelial cells and recruits neutrophils and dendritic cells. The $\mathrm{T}_{\mathrm{H}} 17$ cells, when in contact with antigens at the infection site, are stimulated to synthesize and release cytokines such as IL-17. The pro-inflammatory nature of this cytokine has been related to various inflammatory reactions, and in the mammary gland of cattle it is possibly related to the recruitment of neutrophils in the presence of chronic infection caused by $S$. aureus (Riollet et al., 2006). In vivo studies conducted by Tao and Mallard (2007) also show the transcription of $I L-17$ induced by $S$. aureus in mammary gland cells. Another cytokine, IL-12, a mediator between innate and acquired immunity, is produced by $\mathrm{T}$ lymphocytes and dendritic cells. This protein regulates the differentiation of $\mathrm{T}$ lymphocytes and acts as an endogenous adjuvant in the recruitment of neutrophils, which upon arriving at the infection site phagocytose the invading bacteria and release antibacterial peptides, among other compounds (Oviedo-Boyso et al., 2007).

Lahouassa et al. (2007) also observed an increased expression of $G R O-\alpha$ in mammary epithelial cells stimulated with different strains of $S$. aureus and E. coli. However, the peak production of this cytokine observed by those authors happened $3 \mathrm{~h}$ after infection with the different strains of $S$. aureus and $24 \mathrm{~h}$ after infection by $E$. coli, a similar pattern to that found here with $S$. agalactiae, in which the peak expression of GRO- $\alpha$ occurred $24 \mathrm{~h}$ after inoculation of the pathogen. This shows that different species of bacteria generate distinct patterns of immune response to intramammary infection, making it necessary to study the gene expression in response to mastitis caused by different species of pathogens, both in taurine and zebuine animals.

Chemokines are a specific class of cytokines that mediate the recruitment of effector cells to the inflammation site. CCL2 is the key chemokines for recruitment of monocytes which compose the second line of cellular immune defense. It is important for innate immunity and also helps initiate the humoral immune response (Schukken et al., 2011). Only a few studies have reported inflammation induced by the increased expression of CCL2 in the udder and mammary epithelial cells (Lutzow et al., 2008; Mount et al., 2009; Strandberg et al., 2005). The present study presents the first report of an increase in the expression of this gene during intramammary infection caused by $S$. agalactiae in zebuine cattle. CCL20 is a chemokine that interacts with the CCR6 receptor (Schutyser et al., 2003) and the CCL20-CCR6 pair is responsible for the chemoattraction of immature dendritic cells, $\mathrm{T}$ effector cells and B cells. Other studies have also revealed an increase in the expression of CCL20 in the udder and mammary epithelial cells infected by E. coli (Günther et al., 2009, 2010).

There was clear individual variation among the animals, because some presented much greater changes in the number of somatic cells than others. This variation of initial response might also have happened in the expression of the genes analyzed before inoculation of the pathogen. Base expression levels of some cytokines have also been found in in vitro experiments (Lahouassa et al., 2007; Okada et al., 1997). For in vivo experiments, in which it is even harder to control the conditions, this difference in expression even before inoculation is understandable and cannot be taken as a failure of experimental control. In addition, because the lactating mammary gland is considered part of the mucosal immune system (Brandtzaeg, 2010), it has some particularities. It is estimated that at least $90 \%$ of the microorganisms that infect humans use the mucosa for entry (Brandtzaeg, 2010). For this reason, this system contains a large number of effector lymphocytes, even in the absence of disease (Tanoue et al., 2010). In counterpart, there are powerful regulatory mechanisms that prevent these local responses from getting out of control (Bailey et al., 2001). This can be one more reason for the difference in expression between the inoculated and non-inoculated quarters at hour 0 . In turn, the difference in the expression of the genes considered in this study $24 \mathrm{~h}$ after inoculation between the IQ and NIQ can be an indication that the genes AATK, CCL2, CCL20, CD40, GRO- $\alpha$, IL-17, INHBA, TLR-2 and $T L R-4$ are mainly expressed at the infection site, at the place of action of their products.

Some differentially expressed genes identified through microarray technique, but not validated by qPCR perform functions related to tissue repair during inflammation, such as genes $D C N$, FGF2 and GJA1, which participate in TGF- $\beta$ pathway (Larson et al., 2001; Merline et al., 2009; Xiao et al., 2012). While CH25H gene expression is induced when cells are activated with toll-like receptor ligands, suggesting a possible role in the regulation of the innate immune system (Diczfalusy et al., 2009).

During bacterial infection of the bovine mammary gland, a large number of leukocytes migrate to the udder to establish the response against the pathogen. However, the population of leukocytes that mediate this immune response is not yet well defined (Schukken et al., 2011). Studies of gene expression related to the immune response can help to better characterize this population and to understand how the host responds to a determined pathogenic microorganism. Besides this, the protective immunity of the bovine mammary gland against natural infection by bacteria is relatively brief, only lasting a few weeks (Schukken et al., 2009; Suojala et al., 2008). This incapacity of long-term defense against natural infection poses a significant challenge to the development of effective vaccines against mastitis (Schukken et al., 2011). Once again, the knowledge generated by studies of the expression of candidate genes can help in the selection of better adapted and more productive animals, enabling a reduced need to administer drugs, with consequent reduction of production costs and levels of contamination of dairy products and the environment.

\section{Conclusion}

In this study it was possible to verify changes in the expression of at least 14 genes (AATK, CCL2, CCL20, CD40, CSF2, GRO- $\alpha$, IL-12, IL-17, IL-1 $\beta$, INHBA, NOS2A, TGF- $\beta 1$, TLR-2 e TLR-4) related to the immune response of zebuine animals against intramammary infection caused by $S$. agalactiae. The analysis indicated an increase in the expression of all the genes that presented a significant difference in relation to hour 0 , with most of them presenting maximum expression $24 \mathrm{~h}$ after inoculation of the pathogen. These genes can play important roles in fighting intramammary infection and maintaining the tissue during infection.

\section{Conflict of interest statement}

We wish to draw the attention of the Editor to the following facts which may be considered as potential conflicts of interest 
and to significant financial contributions to this work.

We wish to confirm that there are no known conflicts of interest associated with this publication and there has been no significant financial support for this work that could have influenced its outcome.

We confirm that the manuscript has been read and approved by all named authors and that there are no other persons who satisfied the criteria for authorship but are not listed. We further confirm that the order of authors listed in the manuscript has been approved by all of us.

We confirm that we have given due consideration to the protection of intellectual property associated with this work and that there are no impediments to publication, including the timing of publication, with respect to intellectual property. In so doing we confirm that we have followed the regulations of our institutions concerning intellectual property.

We further confirm that any aspect of the work covered in this manuscript that has involved experimental animals has been conducted with the ethical approval of all relevant bodies and that such approvals are acknowledged within the manuscript.

\section{Acknowledgments}

Funding for this study was provided by Conselho Nacional de Desenvolvimento Científico e Tecnológico (CNPq), Brazil (471914/ 2008 8), Fundação de Amparo à Pesquisa do Estado de Minas Gerais (FAPEMIG) (PPM CVZ - 00059-09), and Embrapa-Agrofuturo (01.06.9.01.03.04) and Coordenação de Aperfeiçoamento de Pessoal de Nivel Superior (CAPES) (CAPES/PROEX (scholarship)).

\section{References}

Alluwaimi, A.M., Leutenegger, C.M., Farver, T.B., Rossitto, P.V., Smith, W.L., Cullor, J. S., 2003. The cytokine markers in Staphylococcus aureus mastitis of bovine mammary gland. J. Vet. Med. B Infect. Dis. Vet. Public Health 50, 105-111.

Bailey, M., Plunkett, F.J., Rothkötter, H.-J., Vega-Lopez, M.A., Haverson, K., Stokes, C. R., 2001. Regulation of mucosal immune responses in effector sites. Proc. Nutr. Soc. 60, 427-435.

Bannerman, D.D., Paape, M.J., Lee, J.W., Zhao, X., Hope, J.C., Rainard, P., 2004. Escherichia coli and Staphylococcus aureus elicit differential innate immune responses following intramammary infection. Clin. Diagn. Lab. Immunol. 11, 463-472.

Bannerman, D.D., Paape, M.J., Goff, P.P., Kimura, K., Lippolis, J.D., Hope, J.C., 2004b. Innate immune response to intramammary infection with Serratia marcescens and Streptococcus uberis. Vet. Res. 35, 681-700.

Bannerman, D.D., Chockalingam, A., Paape, M.J., Hope, J.C., 2005. The bovine innate immune response during experimentally-induced Pseudomonas aeruginosa mastitis. Vet. Immunol. Immunopathol. 107, 201-215.

Bannerman, D.D., 2009. Pathogen-dependent induction of cytokines and other soluble inflammatory mediators during intramammary infection of dairy cows. J. Anim. Sci. 87, 10-25.

Brandtzaeg, P., 2010. The mucosal immune system and its integration with the mammary glands. J. Pediatr. 156, S8-15.

Cates, E.A., Connor, E.E., Mosser, D.M., Bannerman, D.D., 2009. Functional characterization of bovine TIRAP and MyD88 in mediating bacterial lipopolysaccharide-induced endothelial NF-kappaB activation and apoptosis. Comp. Immunol. Microbiol. Infect. Dis. 32, 477-490.

Chockalingam, A., Paape, M.J., Bannerman, D.D., 2005. Increased milk levels of transforming growth factor- $\alpha, \beta 1$, and $\beta 2$ during Escherichia coli-induced mastitis. J. Dairy Sci. 88, 1986-1993.

Contreras, G.A., Rodríguez, J.M., 2011. Mastitis: comparative etiology and epidemiology. J. Mamm. Gland Biol. Neoplasia 16, 339-356.

Cui, X.G., Hwang, J.T.G., Qiu, J., Blades, N.J., Churchill, G.A., 2005. Improved statistical tests for differential gene expression by shrinking variance components estimates. Biostatistics 6, 59-75.

Denis, M., Parlane, N.A., LacyHulbert, S.J., Summers, E.L., Buddle, B.M., Wedlock, D. N., 2006. Bactericidal activity of macrophages against Streptococcus uberis is different in mammary gland secretions of lactating and drying off cows. Vet. Immunol. Immunopathol. 114, 111-120.

Diczfalusy, U., Olofsson, K.E., Carlsson, A.M., Gong, M., Golenbock, D.T., Rooyackers, O., Flaring, U., Bjorkbacka, H., 2009. Marked upregulation of cholesterol 25hydroxylase expression by lipopolysaccharide. J. Lipid Res. 50, 2258-2264.

Embrapa Gadode Leite. 2005. Sistema de Produção. 〈http://sistemasdeproducao.
cnptia.embrapa.br/FontesHTML/Leite/LeiteRecriadeNovilhas/racas.htm $>$ (accessed 30.04.2015).

Estes, D.M., Tuo, W., Brown, W.C., Goin, J., 1998. Effects of type I/type II interferons and transforming growth factor- $\beta$ on B-cell differentiation and proliferation: definition of costimulation and cytokine requirements for immunoglobulin synthesis and expression. Immunology 95, 604-611.

Fagarasan, S., Honjo, T., 2004. Regulation of IgA synthesis at mucosal surfaces. Curr. Opin. Immunol. 16, 277-283.

Fonseca, I., Silva, P.V., Lange, C.C., Guimarães, M.F.M., Weller, M.M.C.A., Sousa, K.R.S. Lopes, P.S., Guimarães, J.D., Guimarães, S.E.F., 2009. Expression profile of genes associated with mastitis in dairy cattle. Genet. Mol. Biol. 32, 776-781.

Fonseca, I., Antunes, G.R., Paiva, D.S., Lange, C.C., Guimarães, S.E.F., Martins, M.F., 2011. Differential expression of genes during mastitis in Holstein-Zebu crossbreed dairy cows. Genet. Mol. Res. 10, 1295-1303.

Fuller, T.F., Ghazalpour, A., Athen, J.E., Drake, T.A., Lusis, A.J., Horvath, S., 2007. Weighted gene coexpression network analysis strategies applied to mouse weight. Mamm. Genome 18, 463-472.

Gaddy-Kurten, D., Tsuchida, K., Vale, W., 1995. Activins and the receptor serine kinase superfamily. Recent Prog. Horm. Res. 50, 109-129.

Gentleman, R.C., Carey, V.J., Bates, D.M., Bolstad, B., Dettling, M., Dudoit, S., Ellis, B. Gautier, L., Ge, Y., Gentry, J., Hornik, K., Hothorn, T., Huber, W., Iacus, S., Irizarry, R., Leisch, F., Li, C., Maechler, M., Rossini, A.J., Sawitzki, G., Smith, C., Smyth, G., Tierney, L., Yang, J.Y.H., Zhang, J., 2004. Bioconductor: open software development for computational biology and bioinformatics. Genome Biol. 5, R80.

Goldammer, T., Zerbe, H., Molenaar, A., Schuberth, H.J., Brunner, R.M., Kata, S.R., Seyfert, H.M., 2004. Mastitis increases mammary mRNA abundance of $\beta$-defensin 5, Toll-like-receptor 2 (TLR2), and TLR4 but not TLR9 in cattle. Clin. Diagn. Lab. Immunol. 11, 174-185.

Griesbeck-Zilch, B., Meyer, H.H., Kuhn, C.H., Schwerin, M., Wellnitz, O., 2008. Staphylococcus aureus and Escherichia coli cause deviating expression profiles of cytokines and lactoferrin messenger ribonucleic acid in mammary epithelial cells. J. Dairy Sci. 91, 2215-2224.

Grönlund, U., Johannisson, A., Waller, K.P., 2006. Changes in blood and milk lymphocyte sub-populations during acute and chronic phases of Staphylococcus aureus induced bovine mastitis. Res.Vet. Sci. 80, 147-154.

Grutz, G., 2005. New insights into the molecular mechanism of interleukin-10mediated immunosuppression. J. Leukoc. Biol. 77, 3-15.

Günther, J., Koczan, D., Yang, W., Nürnberg, G., Repsilber, D., Schuberth, H.J., Park, Z. Maqbool, N., Molenaar, A., Seyfert, H.M., 2009. Assessment of the immune capacity of mammary epithelial cells: comparison with mammary tissue after challenge with Escherichia coli. Vet. Res. 40, 31-39.

Günther, J., Liu, S., Esch, K., Schuberth, H.J., Seyfert, H.M., 2010. Stimulated expression of TNF- $\alpha$ and IL-8, but not of lingual antimicrobial peptide reflects the concentration of pathogens contacting bovine mammary epithelial cells. Vet. Immunol. Immunopathol. 135, 152-157.

Ibeagha-Awemu, E.M., Lee, J.W., Ibeagha, A.E., Bannerman, D.D., Paape, M.J., Zhao, X., 2008. Bacterial lipopolysaccharide induces increased expression of toll-like receptor (TLR) 4 and downstream TLR signaling molecules in bovine mammary epithelial cells. Vet. Res. 39, 11.

Keefe, G.P., 1997. Streptococcus agalactiae mastitis: a review. Can. Vet. J 38, 429-437.

Kerr, D.E., Wellnitz, O., 2003. Mammary expression of new genes to combat mastitis. J. Anim. Sci 81, 38-47.

Kolls, J.K., McCray, P.B., Chan, Y.R., 2008. Cytokine-mediated regulation of antimicrobial proteins. Nat. Rev. Immunol 8, 829-835.

Lahouassa, H., Moussay, E., Rainard, P., Riollet, C., 2007. Differential cytokine and chemokine responses of bovine mammary epithelial cells to Staphylococcus aureus and Escherichia coli. Cytokine 38, 12-21.

Langfelder, P., Horvath, S., 2008. WGCNA: An R package for weighted correlation network analysis. BMC Bioinformatics 9, 559.

Larson, D.M., Christensen, T.G., Sagar, G.D.V., 2001. TGF- $\beta 1$ induces an accumulation of Connexin43 in a lysosomal compartment in endothelial cells. Endothelium 8 $1-6$.

Lee, J.W., Bannerman, D.D., Paape, M.J., Huang, M.K., Zhao, X., 2006. Characterization of cytokine expression in milk somatic cells during intramammary infections with Escherichia coli or Staphylococcus aureus by real-time PCR. Vet. Res. 37, 219-229.

Leutenegger, C.M., Alluwaimi, A.M., Smith, W.L., Perani, L., Cullor, J.S., 2000. Quantitation of bovine cytokine mRNA in milk cells of healthy cattle by realtime TaqMan polymerase chain reaction. Vet. Immunol. Immunopathol. 77, 275-287.

Long, E., Capuco, A.V., Wood, D.L., Sonstegard, T., Tomita, G., Paape, M.J., Zhao, X., 2001. Escherichia coli induces apoptosis and proliferation of mammary cells. Cell Death Differ. 8, 808-816.

Lutzow, Y., Donaldson, L., Gray, C., Vuocolo, T., Pearson, R., Reverter, A., Byrne, K., Sheehy, P., Windon, R., Tellam, R., 2008. Identification of immune genes and proteins involved in the response of bovine mammary tissue to Staphylococcus aureus infection. BMC Vet. Res. 4, 18-25.

Merline, R., Lazaroski, S., Babelova, A., Tsalastra-greul, W., Pfeilschifter, J., Schluter, K.D., Gunther, A., Iozzo, R.V., Schaefer, R.M., Schaefer, L., 2009. Decorin deficiency in diabetic mice: aggravation of nephropathy due to overexpression of profibrotic factors, enhanced apoptosis and mononuclear cell infiltration. J. Physiol. Pharmacol. 60 (Suppl. 4), 5-13.

Mount, J., Karrow, N., Caswell, J., Boermans, H., Leslie, K., 2009. Assessment of bovine mammary chemokine gene expression in response to lipopolysaccharide lipotechoic acid + peptidoglycan, and CpG oligodeoxynucleotide 2135. Can. J. Vet. Res. 73, 49-57. 
Neave, F.K., Dodd, F.H., Kingwill, R.G., Westgarth, D.R., 1969. Control of mastitis in the dairy herd by hygiene and management. J. Dairy Sci. 52, 696-707.

NMC, 1987. Laborartory and Field Handbook on Bovine Mastitis. National Mastitis Council, Arlington, VA.

Okada, H., Ito, T., Ohtsuka, H., Kirisawa, R., Iwai, H., Yamashita, K., Yoshino, T., Rosol, T.J., 1997. Detection of interleukin-1 and interleukin-6 on cryopreserved bovine mammary epithelial cells in vitro. J. Vet. Med. Sci. 59, 503-507.

Oviedo-Boyso, J., Valdez-Alarcón, J.J., Cajero-Juárez, M., Ochoa-Zarzosa, A., LópezMeza, J.E., Bravo-Patiño, A., Baizabal-Aguirre, V.M., 2007. Innate immune response of bovine mammary gland to pathogenic bacteria responsible for mastitis. J. Infect. 54, 399-409.

Paape, M.J., Bannerman, D.D., Zhao, X., Lee, J.W., 2003. The bovine neutrophil: structure and function in blood and milk. Vet. Res. 34, 597-627.

Petzl, W., Zerbe, H., Gunther, J., Yang, W., Seyfert, H., Nurnberg, G., Schuberth, H., 2008. Escherichia coli, but not Staphylococcus aureus triggers an early increased expression of factors contributing to the innate immune defense in the udder of the cow. Vet. Res. 39, 18

R Development Core Team, 2010. R: A Language and Environment for Statistical Computing. R Foundation for Statistical Computing, Vienna, Austria.

Rainard, P., Riollet, C., 2003. Mobilization of neutrophils and defense of the bovine mammary gland. Reprod. Nutr. Dev. 43, 439-457.

Rainard, P., Riollet, C., 2006. Innate immunity of the bovine mammary gland. Vet. Res. 37, 369-400.

Richards, V.P., Lang, P., Bitar, P.D.P., Lefébure, T., Schukken, Y.H., Zadoks, R.N., Stanhope, M.J., 2011. Comparative genomics and the role of lateral gene transfer in the evolution of bovine adapted Streptococcus agalactiae. Infect. Genet. Evol. $11,1263-1275$

Rinaldi, M., Li, R.W., Bannerman, D.D., Daniels, K.M., Evock-Clover, C., Silva, M.V.B. Paape, M.J., Ryssen, B.V., Burvenich, C., Capuco, A.V., 2010. A sentinel function for teat tissues in dairy cows: dominant innate immune response elements define early response to E. coli mastitis. Funct. Integr. Genomics 10, 21-38.

Riollet, C., Mutuel, D., Duonor-Cérutti, M., Rainard, P., 2006. Determination and characterization of bovine interleukin-17 cDNA. J. Interferon Cytokine Res. 26 141-149.

Schukken, Y.H., Hertl, J., Bar, D., Bennett, G.J., González, R.N., Rauch, B.J., Santisteban, C., Schulte, H.F., Tauer, L., Welcome, F.L., Gröhn, Y.T., 2009. Effects of repeated gram-positive and gram-negative clinical mastitis episodes on milk yield loss in Holstein dairy cows. J. Dairy Sci. 92, 3091-3105.

Schukken, Y.H., Gunther, J., Fitzpatrick, J., Fontaine, M.C., Goetze, L., Holst, O., Leigh, J., Petzl, W., Schuberth, H.J., Sipka, A., Smith, D.G.E., Quesnell, R., Watts, J., Yancey, R., Zerbe, H., Gurjar, A., Zadoks, R.N., Seyfert, H.M., 2011. Host-response patterns of intramammary infections in dairy cows. Vet. Immunol. Immunopathol. 144, 270-289.

Schutyser, E., Struyf, S., Van Damme, J., 2003. The CC chemokine CCL20 and its receptor CCR6. Cytokine Growth Factor Rev. 14, 409-426.

Sheffield, L.G., 1997. Mastitis increases growth factor messenger ribonucleic acid in bovine mammary glands. J. Dairy Sci. 80, 2020-2024.

Singh, K., Davis, S.R., Dobson, J.M., Molenaar, A.J., Wheeler, T.T., Prosser, C.G., Farr, V. C., Oden, K., Swanson, K.M., Phyn, C.V., Hyndman, D.L., Wilson, T., Henderson, H.
V., Stelwagen, K., 2008. cDNA microarray analysis reveals that antioxidant and immune genes are upregulated during involution of the bovine mammary gland. J. Dairy Sci. 91, 2236-2246.

Storey, J.D., 2002. A direct approach to false discovery rates. J. R. Stat. Soc. B 64 (Part 3), 479-498.

Strandberg, Y., Gray, C., Vuocolo, T., Donaldson, L., Broadway, M., Tellam, R., 2005. Lipopolysaccharide and lipoteichoic acid induce different innate immune responses in bovine mammary epithelial cells. Cytokine 31, 72-86.

Suojala, L., Orro, T., Jarvinen, H., Saatsi, J., Pyorala, S., 2008. Acute phase response in two consecutive experimentally induced E. coli intramammary infections in dairy cows. Acta Vet. Scand. 50, 18-24.

Tao, W., Mallard, B., Karrow, N., Bridle, B., 2004. Construction and application of a bovine immune-endocrine cDNA microarray. Vet. Immunol. Immunopathol. $101,1-17$.

Tao, W., Mallard, B., 2007. Differentially expressed genes associated with Staphylococcus aureus mastitis of Canadian Holstein cows. Vet. Immunol. Immunopathol. 120, 201-211.

Tanoue, T., Umesaki, Y., Honda, K., 2010. Immune responses to gut microbiotacommensals and pathogens. Gut Microbes 1, 224-233.

The Bovine HapMap Consortium, 2009. Genome-wide survey of SNP variation uncovers the genetic structure of cattle breeds. Science 324, 528-532.

Vandesompele, J., De Preter, K., Pattyn, F., Poppe, B., Van Roy, N., De Paepe, A. Speleman, F., 2002. Accurate normalization of real-time quantitative RT-PCR data by geometric averaging of multiple internal control genes. Genome Biol. 3 (7), research0034.I-0034.II..

Xiao, L., Du, Y., Shen, Y., He, Y., Zhao, H., Li, Z., 2012. TGF-beta 1 induced fibroblast proliferation is mediated by the FGF-2/ERK pathway. Front. Biosci. (Landmark Ed). 17, 2667-2674.

Wang, Y.H., Byrne, K.A.s, Reverter, A., Harper, G.S., Taniguchi, M., McWilliam, S.M., Mannen, H., Oyama, K., Lehnert, S.A., 2005. Transcriptional profiling of skeletal muscle tissue from two breeds of cattle. Mamm. Genome 16; , pp. 201-210.

Wolfinger, R.D., Gibson, G., Wolfinger, E.D., Bennett, L., Hamadeh, H., Bushel, P. Afshari, C., Paules, S., R., 2001. Assessing gene significance from cDNA microarray expression data via mixed models. J. Comput. Biol 8, 625-637.

Wu, H., M.K. Kerr, M.K., Cui, X., Churchill, G.A., 2003. MAANOVA: a software package for the analysis of spotted cDNA microarray experiments. In: Parmigiani, G., Garnett, E., Irizarry, R., Zeger, S. (Eds.), The Analysis of Gene Expression Data: Methods and Software. Springer-Verlag, New York, pp. 313-341.

Yang, W., Zerbe, H., Petzl, W., Brunner, R.M., Gunther, J., Draing, C., von Aulock, S., Schuberth, H.J., Seyfert, H.M., 2008. Bovine TLR2 and TLR4 properly transduce signals from Staphylococcus aureus and E. coli, but $S$. aureus fails to both activate NF-kappaB in mammary epithelial cells and to quickly induce TNFalpha and interleukin-8 (CXCL8) expression in the udder. Mol. Immunol. 45, 1385-1397.

Zadoks, R.N., Middleton, J.R., McDougall, S., Katholm, J., Schukken, Y.H., 2011. Molecular epidemiology of mastitis pathogens of dairy cattle and comparative relevance to humans. J. Mamm. Gland Biol. Neoplasia 16, 357-372.

Zhao, X., Lacasse, P., 2008. Mammary tissue damage during bovine mastitis: causes and control. J. Anim. Sci. 86, 57-65. 